\title{
A WASTE BANK BASED ON THE 3R CONCEPT: STUDENT INTEREST IN WASTE MANAGEMENT AT THE DEPARTMENT OF ECONOMICS, UNIVERSITY OF BRAWIJAYA
}

\author{
Sri MULJANINGSIH ${ }^{1, *}$ \\ ${ }^{1}$ Faculty of Economy and Business, University of Brawijaya, JI. MT. Haryono No.165, Ketawanggede, \\ Kec. Lowokwaru, Malang, East Java 65145, Indonesia. \\ corresponding author: muljaningsih@ub.ac.id
}

\section{Abstract}

The establishment of a waste bank could be a social engineering tool for changing the mindset of students. This waste bank can be managed and made useful via the so-called "3R" concept (reduce, reuse, and recycle), which is the main principle used by waste banks. This study aimed to determine students' interest in managing waste. The sample comprised three classes of students who are enrolled in natural resource economics courses from the Economics and Business Faculty of the University of Brawijaya. Each class has 31 students. Quantitative multivariate research was performed using a Likert scale. Validity and reliability tests were performed for behavioral control and to manage waste variables. Data analysis was used Multivariate analysis, and Bartlett's test of sphericity was used for significance of the data. Results show that the behavioral control variable was positively correlated with and was influenced by the intention to manage waste or the interest in managing waste. We suggested that waste bank systems-in which waste can be exchanged for food or other products-could be applied in campus environments and that a waste bank should be established in the Faculty of Economics and Business of the University of Brawijaya.
\end{abstract}

\section{Keywords:}

3R concept; Interest in managing waste; Social engineering; Waste bank.

\section{Introduction}

Waste increases with population growth, and the amount of waste generated by a growing population is often not managed properly. A community usually manages waste by using an end-ofpipe approach, in which waste is collected, transported, and disposed of only at final processing [1]. This is the case in almost all Indonesian cities [2]. According to the City of Sanitation and Landscaping Office of Malang, waste always increases. Furthermore, approximately $69 \%$ of landfill waste is generated from domestic waste, and $31 \%$ is generated from non-domestic waste [3]. Law Number 18 in 2008 concerning waste management, along with Government Regulation Number 81 in 2012, created a fundamental paradigm in waste management from the collection-transport-disposal paradigm to the process of waste reduction and handling [4-5]. Therefore, an understanding of waste management is needed.

Recycling requires the cooperation of suppliers, producers, and consumers. The 3R concept (reduce, reuse, and recycle) is fundamental for a waste bank to manage waste and provide economic benefits [6]. A waste bank reduces the volume of waste by following the $3 R$ concept [3]. It is a sustainable form of development that includes economic, social, and environmental aspects [7]. Sustainability is correlated with environmental, economic, and social aspects and has been achieved in Vietnamese urban environments by using the behavioral intention to recycle waste via community participation [8-9].

Several countries, including Canada, the United Kingdom, and Australia, have developed an integrated processing model called zero waste [10]. In Malaysia, waste management is performed in 
accordance with 3R, whereas Bangladesh has found innovative methods for dealing with waste management [11]. Furthermore, waste banks play a vital role as a drop-off point for producers and for product packaging. Bank Sampah Malang (BSM) or Malang Waste Bank is an example of a waste bank in Indonesia that has already reduced waste significantly (i.e., waste has been decreased in Malang by $50 \%$ per day) [12].

Community participation in waste management is crucial in implementing waste banks. BSM offers financial compensation in exchange for participating in waste banks [13]. Waste banks can be implemented in elementary schools, high schools, vocational schools, and universities [14]. By following the example of the City Government of Malang, we recommend that one department of the University of Brawijaya should establish a waste bank. This waste bank can function as a social engineering mechanism by teaching the community to sort waste, increasing public awareness of waste management, and reducing overall waste [3]. The University of Brawijaya is a green campus. Although the university provides waste management on the basis of the $3 R$ principle, it cannot be fully implemented. The campus has a waste management unit for compost (organic waste), but nonorganic waste, such as paper and plastic, has not been managed well [15]. The high volume of waste and the ineffective management of waste increase the budget of maintaining waste [12]. The end-ofpipe approach is a vital solution because this approach focuses on waste management from collection, transportation, and disposal to the final disposal site [16].

Social engineering aims to change the mindset of people with regard to changing rubbish into valuable goods (i.e., trash to cash). Waste banks must be maintained by an entrepreneur because it is related to entrepreneurial concepts and behavior [17]. Entrepreneurial intentions are influenced by social norms, self-efficacy, desirability, and feasibility, which are based on external factors, as well as the theory of reasoned action and the planned action proposed [18]. The theory of reasoned action is related to the theory of planned behavior. Understanding the theory of reasoned action involves understanding beliefs, attitudes, intentions, and behavior.

According to Callan and Thomas [19], psychological entrepreneurship capital is extremely necessary. Intentions and interests are influenced by attitudes, subjective norms, and perceptions on a task's ease or difficulty [20]. It is a basis for someone to act. Therefore, the reason for an action is related to behavioral control.

It is not easy to change an individual's mindset or behavior. The Faculty of Economics and Business of the University of Brawijaya provides natural resource economics courses and environmental economics courses, which provide waste management learning that can lead to added economic value. After finishing these courses, students are expected to have a better understanding of their interest in managing waste, such as paper and plastic waste. A waste bank has been provided in the Department of Regional and City Planning, Faculty of Engineering, University of Brawijaya. Therefore, it is necessary to conduct this research to determine the effectiveness of the natural resource economics and environmental economics courses in affecting students' interest in managing waste via waste banks. To the best of our knowledge, no study has been conducted on this topic in Indonesia.

\section{Materials and methods}

\subsection{Research design and respondents}

Data were obtained via quantitative research methods. This research was conducted in 2018. A survey was administered to 90 students enrolled in natural resource economics courses in the Department of Economics of the University of Brawijaya. Furthermore, the students were educated about the waste Bank in Malang to assist them in establishing a waste bank in the Department of Economics.

\subsection{Data collection}

The data was collected by distributing questionnaires to the respondent. Behavioral control is used as an independent variable and intention to manage or interest in waste management is used as the dependent variable. These variables are derived into questions that include behavioral control, which consisted of: participation in waste management, actively managing waste, being able to sort waste, and conducting environmental protection campaigns. Each question requires the respondent to choose between strongly agree, agree, neutral, disagree, or strongly disagree. The data from the 
questionnaire results were then converted using a Likert scale from one (strongly disagree) to five (strongly agree).

\subsection{Data analysis}

This study uses independent variables using control behavior variables. Meanwhile, the dependent variable uses several variables that describe the interest or intention of waste management behavior. Multivariate analysis was performed because this study involved more than one dependent variable, namely, participation in waste management, helping in waste management, and being the customer. The results of the questionnaire in the form of scores are used as data input and then further statistical analysis will be carried out.

The first analysis conducted in this study was factor analysis. Factor analysis aims to form factors from the indicators of research variables in order to obtain the dominant variable that can be used or selected for further analysis, namely regression analysis. There are assumptions that must be fulfilled in the factor analysis, namely the assumption of the adequacy of the sample tested using the Barlett test of sphericity. The factor score (new variable) as a linear combination of the original variables can be written as follows:

$F_{i}=W_{i 1} X_{1}+W_{R} X_{2}+W_{i 3} X_{3}+\ldots \ldots+W_{i k} X_{k}$

where $F_{i}$ is score (value) of $i$ factor, $W_{i}$ is the coefficient of $i$ factor score, $k$ is number of original variables.

The second analysis is to test the validity of answers from the respondent, the validity and reliability tests were carried out which met the requirements. After this is done, the data that has been collected will be tested statistically. Linear regression analysis was also used to review the effect on each variable. Given that this study uses interval data with a Likert scale, validity and reliability tests were performed on respondents' questionnaires. Validity was determined by comparing the Pearson product-moment correlation coefficient $r$ against the item score $X$ and the total score of corresponding items $Y$ with $\alpha=5 \%$. Reliability was analyzed using Cronbach's alpha as follows (Eq. 1). All data analysis was performed using SPSS ver. 20 [21].

$r_{11}=\left(\frac{k}{k-1}\right) \times\left(1-\frac{\sum \sigma_{b}^{2}}{\sigma_{t}^{2}}\right)$,

where $r_{11}$ is the reliability of the instrument (Cronbach's alpha coefficient), $k$ is the number of questions, $\Sigma \sigma 2 / b$ is the number of item variances, and $\sigma 2 / t$ is the total variance.

\section{Results and discussion}

\subsection{The validity of behavioral control}

The requirements for factor analysis were fulfilled. Factor analysis results for behavioral control variables produce a factor score. On the basis of the existing factor score, the behavioral control factor is formed by the student's decision to manage waste in the Department of Economics. A validity test was performed to analyze qualitative data from questionnaires by using a Likert scale. Table 1 shows the validity test results for the behavioral control variable. The table shows that sig. $<0.05$ for all indicators in the variable of behavioral control. Therefore, the indicators are valid and useful for further analysis.

Table 1: Validity test results for the behavioral control variable.

\begin{tabular}{|c|c|c|c|c|}
\hline Item & Indicator & Correlation & Sig. & Noted \\
\hline 1 & Participated in managing waste in the Department of Economics & 0.846 & 0.000 & Valid \\
\hline 2 & Active in managing waste in the Department of Economics & 0.800 & 0.000 & Valid \\
\hline 3 & Able to sort waste & 0.506 & 0.000 & Valid \\
\hline 4 & Held a campaign to protect the environment in the University of Brawijaya & 0.900 & 0.000 & Valid \\
\hline
\end{tabular}




\subsection{Validity test of intention and interest in managing waste}

A validity test was performed to analyze qualitative data from questionnaires by using a Likert scale. Table 2 shows the validity test results for the intention to manage or interest in managing waste variables. The table shows that sig. $<0.05$ for all indicators against the intention to manage waste. Therefore, the indicators are valid and useful for further analysis.

Table 2: Validity test results: Intention to manage waste.

\begin{tabular}{|c|c|c|c|c|}
\hline Item & Indicator & Correlation & Sig. & Noted \\
\hline 1 & Participating in waste management in the Department of Economics & 0.919 & 0.000 & Valid \\
\hline 2 & Helping in the waste management in the Department of Economics & 0.890 & 0.000 & Valid \\
\hline 3 & Being a customer of the waste bank in the Department of Economics & 0.920 & 0.000 & Valid \\
\hline
\end{tabular}

The intention to manage waste is related to the theory of reasoned action and the theory of planned behavior [22]. This intention is influenced by attitudes, subjective norms, and perceptions about the ease or difficulty of completing a task. In principle, the intention has a strong relationship with behavior. Subjective norms refer to a person's trust in taking action. The perception of whether an action is easy or difficult to perform is based on beliefs that affect one's intentions. This intention is influenced by a person's attitude toward taking action. Furthermore, interest in a product is influenced by consumer attitudes [23]. The interest in managing waste is expected to manifest into a real behavioral attitude because knowledge about minimizing waste can affect behavioral attitudes, and waste management behavior can be cultivated by enrolling in natural resource economics and environmental economics courses, which provide knowledge about conserving natural resources [24]

\subsection{Reliability test results}

The reliability test is used to determine the consistency of a research instrument. If a research instrument has a Cronbach's alpha value $>0.60$, it is considered reliable. Table 3 shows the reliability test results. The table shows that both the behavioral control and intention to manage waste variables have a Cronbach's alpha value greater than 0.8. Considering that this value is above the threshold of 0.69 , it is considered reliable.

Table 3: Results of reliability test against research variable.

\begin{tabular}{|c|c|c|c|}
\hline Item & Indicator & Cronbach's alpha & Note \\
\hline 1 & Behavioral control & 0.823 & Reliable \\
\hline 2 & Intention to manage waste & 0.885 & Reliable \\
\hline
\end{tabular}

\subsection{Analysis of behavioral control}

Factor analysis, which is a multivariate form of analysis, was performed on the behavioral control variable. Table 4 shows the factor analysis for the behavioral control variable. The adequacy value of the sample for the behavioral control variable was 0.727 (more than 0.60 ). Bartlett's test of sphericity indicates that it was significant (sig. <0.05).

Table 4. Results of factor analysis and rotational factor against behavioral control variable.

\begin{tabular}{|c|c|c|}
\hline Indicator & \multicolumn{2}{|c|}{ Factor score } \\
\hline Participated in management waste in the Department of Economics & \multicolumn{2}{|c|}{0.904} \\
\hline Active in managing waste in the Department of Economics & \multicolumn{2}{|c|}{0.907} \\
\hline Able to sort waste & \multicolumn{2}{|c|}{0.696} \\
\hline Held a campaign to protect the environment in the University of Brawijaya & \multicolumn{2}{|c|}{0.752} \\
\hline Adequacy value of a sample & \multicolumn{2}{|c|}{0.727} \\
\hline \multirow{2}{*}{ Bartlett's test of sphericity } & Chi-square & 57.486 \\
\hline & Sig. & 0.000 \\
\hline
\end{tabular}

Behavioral control refers to a person's perception in performing certain behavior, and it is determined by beliefs and factors that facilitate or complicate a particular behavior [25]. Sadiku and 
Sylaj [26] stated that family and environment influence student behavior, including student interest in managing waste. Student behavior is influenced by the campus environment, such as knowledge gained in natural resource economics and environmental economics courses, which can trigger active participation in waste management in the Department of Economics. It may also be influenced by a family environment that provides education in managing waste. The behavior of beach workers in Bali toward tourists from Japan is considered impolite, but the beach workers are not aware of their mistakes owing to cultural differences. Culture can be understood as a habit, and behavior with regard to waste management can be considered a form of habit. Culture and habits are determined by several factors in accordance with the theory of acting style and is related to internal and external control. It can be part of the culture associated with behavioral control [18]. The behavior of managing waste can be related to community culture as an external control and the individual as an internal control. Therefore, the control of student behavior could focus on managing culture-related waste.

Table 5: Analysis and rotational factor against the intention to manage waste.

\begin{tabular}{|c|c|c|}
\hline Indicator & \multicolumn{2}{|c|}{ Factor score } \\
\hline Participation in managing waste in the Department of Economics & \multicolumn{2}{|c|}{0.960} \\
\hline Intention to help waste management in the Department of Economics & \multicolumn{2}{|c|}{0.925} \\
\hline Intention to become a customer of waste bank & \multicolumn{2}{|c|}{0.826} \\
\hline Adequacy value of a sample & \multicolumn{2}{|c|}{0.636} \\
\hline \multirow{2}{*}{ Bartlett's test of sphericity } & Chi-square & 65.470 \\
\cline { 2 - 3 } & Sig. & 0.000 \\
\hline
\end{tabular}

All requirements for the validity of factor analysis have been fulfilled. The primary indicator was student intention to manage waste in the Department of Economics, as determined by its higher factor score in corresponding indicators than the other indicators. Table 5 shows the results of factor analysis in managing waste. Only a factor is formed against the intention to manage. The adequacy value of the sample for the intention to manage the variable was 0.636 (more than the threshold of 0.60). Furthermore, Bartlett's test of sphericity indicated that it was significant (sig. <0.05).

Therefore, as shown in Table 5, the intention of students to be involved in the waste management process is influenced by three factors, namely, student participation in waste management, student intention in helping to manage waste, and student intention to become customers of waste banks. This shows that the higher involvement of students in the waste management program will further strengthen the intention of students to actively manage waste both inside and outside the campus. This is in accordance with the results of Michaelidou and Hassan [23] who showed that there is a strong correlation between one's intentions and attitudes. When a person's attitude is more positive toward an action, that person will have a greater intention to perform that action.

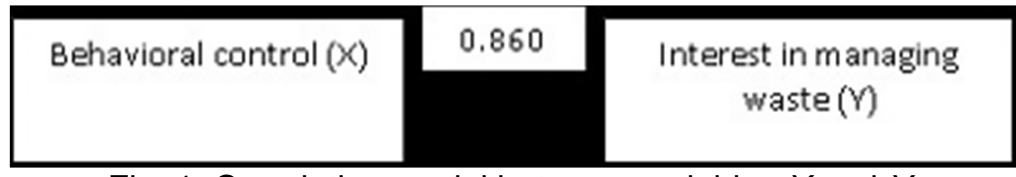

Fig. 1: Correlation model between variables $X$ and $Y$.

Table 6: Regression coefficient.

\begin{tabular}{|c|c|c|c|c|c|}
\hline \multirow{2}{*}{} & \multicolumn{2}{|c|}{ Unstandardized coefficients } & Standardized coefficients & $\boldsymbol{T}$ & Sig. \\
\cline { 2 - 6 } & B & Std. Error & Beta & & \\
\hline Control & 0.860 & 0.095 & 0.860 & 9.085 & 0.000 \\
\hline (Constant) & $-2.149 \mathrm{E}-17$ & 0.093 & & 0.000 & 1.000 \\
\hline
\end{tabular}

Table 6 shows a regression coefficient against the variable of behavior control. Fig. 1 shows the relationship model between interest in managing waste and behavioral control. Linear regression analysis was performed to determine the relationship model between the control of the behavior variable $X$ with the intention or interest in managing the waste variable $Y$. The results show that behavioral control as an independent variable $X$ influences and is positively correlated with the 
intention or interest to manage waste as a dependent variable $Y$. The coefficient for control of behavior was 0.86 , with $\alpha=5 \%$.

In this study, behavioral control is defined as a student's ability to participate in managing waste. This research is limited to interests or intentions in managing waste, but these intentions can become a moderator variable for actual behavior. In the theory of planned behavior, behavioral control directly affects a person's intention to perform an action and influences behavior in situations wherein a person intends to perform an action but is prevented from doing so [27-28]. Perceived behavioral control is demonstrated by one's response to internal or external obstacles when engaging in a certain action. In this case, the control given to students originates from the introduction of students to waste management, e.g., classroom lessons and waste management activities. Both of these factors will create conditions that can foster the intentions of students in managing waste.

As shown in Table 7, behavioral control affects the interest in managing waste of students enrolled in natural resource economics and environmental economics courses. However, by participating in the activity, the students will play an important role in a restoration that will be a new goal both economic and environmental. Also, it will train the students to be active to prevent pollution and protect human health by practicing waste management [29]. These findings reveal that the behavioral control of students enrolled in natural resource economics and environmental economics courses encourages their interest in managing waste. Students who are enrolled in natural resource economics and environmental economics courses can participate in managing waste in the Department of Economics. Thus, the waste bank is planned in the Department of Economics.

Table 7: Regression models.

\begin{tabular}{|c|c|c|c|c|c|c|}
\hline Model & $\mathbf{R}$ & R-square & $\begin{array}{c}\text { Adjusted } \\
\text { R-square }\end{array}$ & $\begin{array}{c}\text { Std. error of the } \\
\text { estimate }\end{array}$ & $\begin{array}{c}\text { Dependent } \\
\text { variable }\end{array}$ & $\begin{array}{c}\text { Independent } \\
\text { variable }\end{array}$ \\
\hline 1 & $0.888^{\mathrm{a}}$ & 0.789 & 0.746 & 0.50359746 & $\begin{array}{c}\text { Interest or intention } \\
\text { to manage waste }\end{array}$ & Behavioral control \\
\hline
\end{tabular}

\section{Conclusion}

The condition of waste management in the Department of Economics, Universitas Brawijaya cannot yet be determined, but the results of the research show that students are interested or enthusiastic in waste management. Behavioral control variables have a direct effect on interest or intention to manage waste. According to the perception of students who are taking natural resource economics and environmental economics courses, managing waste is considered easy enough, so they are interested in managing waste. There is a positive correlation between behavior control and intention or interest. Thus, it is necessary to review the relationship between intention or interest in managing waste and business behavior in managing waste in the form of Garbage Bank in the Department of Economics.

\section{Acknowledgement}

The funding research was from the budget allocated for the DPP of Economic and Business Faculty, University of Brawijaya. Therefore, the author gratefully acknowledges the help provided by the Dean. Furthermore, the author would like to thank the colleagues who helped the implementation of this research.

\section{References}

[1] HERLAMBANG, A. - MARTONO D. H.: Teknologi pengolahan sampah dan air limbah [Waste management and liquid waste technology]. Jurnal Air Indonesia, Vol. 4, 2008, pp. 146-160.

[2] SAHWAN F. L.: Tempat pengelolaan sampah terpadu (TPST) urgensi dan implementasinya [Waste treatment centre urgencies and their implementations]. Jurnal Rekayasa Lingkungan, Vol. 6, 2010, pp. 151-157.

[3] PRATAMA, R. A. - IIF, M. I.: The opportunities to strengthen the role of bank sampah to reduce municipal waste case study: Bank Sampah Malang. Jurnal Teknik Lingkungan, Vol. 18, 2017, pp. 112-119.

[4] GOVERNMENT OF INDONESIAN REPUBLIC: Peraturan pemerintah RI No.81 Tahun 2012Pengelolaan sampah rumah tangga dan sampah sejenis sampah rumah tangga [Republic of Indonesia Government Regulation No. 81/2012 - Management of household waste and householdlike waste]. 2012. https://peraturan.bpk.go.id/Home/Details/5295/pp-no-81-tahun-2012. 
[5] GOVERNMENT OF INDONESIAN REPUBLIC: Undang-undang RI. No.18 tahun 2008 tentang pengelolaan sampah [RI Law. No.18 of 2008 concerning waste management]. 2008. https:// pelayanan.jakarta.go.id/download/regulasi/undang-undang-nomor-18-tahun-2008-tentang-pengelo la an-sampah.pdf.

[6] TIETENBERG, T. - LEWIS, L.: Environmental and natural resource economics, Pearson Education, New York, 2003.

[7] ADAM, W. M.: The future of sustainability: Re-thinking environment and development in the twentyfirst century, IUCN, Gland-Switzerland, 2006. https://portals.iucn.org/library/node/12635.

[8] DALY H. E. - FARLEY J.: Ecological economics, principles, and application, Island Press, Washington-Covelo-London, 2009. http://library.uniteddiversity.coop/Measuring_Progress_and_ EcoFootprinting/Ecological_Economics-Principles_and_Applications.pdf.

[9] NGUYEN, H. T. T. - HUANGG, R. J. - LEE, C. H. - NGUYEN, T. T.: Determinants of residents' ewaste recycling behavioral intention: A case study from Vietnam. Sustainability, Vol. 11, 2018, p. 164.

[10] HSU, E. - KUO, C. M.: Recycling rates of waste home appliances in Taiwan. Waste Management, Vol. 25, 2005, pp. 53-65.

[11] REZA, A. - YOUSUF, T. B.: 3R (Reduce, Reuse, and Recycle) action plan for the city corporations in Bangladesh: Paradigm shift of waste management to resource management. Proceedings of the Waste Safe 2013 - 3rd International Conference on Solid Waste Management in the Developing Countries, 10th-12th of February 2013, Khulna, Bangladesh, 2013.

[12] LESTARI, A. P. - SOEAIDY, M. S. - SAID, A.: Program inovasi pengelolaan sampah di Kota Malang [Innovation of trash management program in Malang City]. Jurnal Administrasi Publik, Vol. 2, 2014, pp. 571-577.

[13] WULANDARI, D. - UTOMO, S. H. - NARMADITYA, B. S.: Waste bank: Waste management model in improving local economy. International Journal of Energy Ecology Policy, Vol. 7, 2017, pp. 36-41.

[14] ARUM, G. S.: Youth participation in collecting and reducing solid waste through educational facilities in Semampir district, Surabaya, ISWA-SWIS Winter School Proceedings. Texas, USA, The University of Texas at Arlington, 2007. http://www.uta.edu/swis/Publications/WS Proceeding_2017. pdf.

[15] MULJANINGSIH, S. - GALUH, A. K.: Intention model of waste management education concept based on green campus in Brawijaya University. Jurnal Pembangunan Alam, Vol. 9, 2018, pp. 129-139.

[16] SURYANTO, D. A. - SUSILOWATI, D.: Kajian potensi ekonomis dengan penerapan 3R (Reduce, reuse dan recycle) pada pengelolaan sampah rumah tangga di Kota Depok [Study of economic potential by implementing 3R (Reduce, reuse and recycle) in household waste management in Depok City]. Proceeding Seminar Nasional PESAT, 23rd-24th of August, 2005, Audiotorium Universitas Gunadarma, Jakarta.

[17] DAVID, K.: Farm management extension guide. entrepreneurship in farming. Rome, FAO, Italy, 2012. http://www.fao.org/sustainable-food-value-chains/training-and-learning-center/details/en/c/ $274677 /$.

[18] AJZEN, I. - FISHBEIN, M.: Attitude and the attitude-behavior relation: Reason and automatic processes, European Review of Social Psychology, Vol. 11, 2010, pp. 1-33.

[19] CALLAN, S. J. - THOMAS, J. M.: Environmental economics \& management: Theory, policy, and applications, The Dryden Press, Harcourt College Publishers, Oak Brook, IL, 2000.

[20] MULJANINGSIH, S.: Entrepreneurial interest in product innovation based organic processed food in SMEs in Malang, Indonesia. Asia-Pacific management and Business Application, Vol. 4, 2018, pp. 83-95.

[21] SARWONO, J.: Mengenal SPSS Statistics 20 Aplikasi untuk riset eksperimental [Getting to know SPSS Statistics 20 Applications for experimental research], Elex Media Komputindo, Jakarta, 2012.

[22] AJZEN, I. - FISHBEIN, M.: Understanding attitude and predicting social behavior. Prentice-Hall, Englewood-Cliffs, NJ, 1980.

[23] MICHAELIDOU, N. - HASSAN, L.M.: Modeling the factors affecting rural consumer's purchase of organic and free-range produce: A case study of consumers' from the Island of Arran in Scotland, UK. Food Policy, Vol. 35, 2010, pp. 130-139.

[24] AKHTAR, H. - SOETJIPTO, H. P.: Peran sikap dalam memediasi pengaruh pengetahuan terhadap perilaku minimisasi sampah pada masyarakat Terban, Yogyakarta [Role of attitude in mediating insight influence towards the waste minimization behaves]. Jurnal Manusia Lingkungan, Vol. 21, 2004, pp. 386-392. 
[25] AJZEN, I. - FISHBEIN, M. M.: The influence of attitudes on behavior. In: Albarracin, D., Johnson, B. T, Zanna, M. P. (Eds.), The Handbook of Attitude, New Jersey, Lawrence Erlbaum Associates, Mahwah, USA, 2005, pp. 173-221.

[26] SADIKU, G. S. - SYLAJ, V.: Factor that influence the level of the academic performance of the students. Journal of Sosial Studies education Research, Vol. 10, 2019, pp. 17-38.

[27] ARNOULD, E. - PRICE, L. - ZINKHAN, G.: Consumers, 2nd ed. Mc Graw Hill, New York, 2005.

[28] WARMANTO, F. - THENU, H. N.: Analisis hubungan antara sikap, norma subyektif, dan kontrol keperilakuan yang dirasakan terhadap perilaku berbagi pengetahuan manajer: Studi empiris pada perusahaan di wilayah Jakarta [Analysis of the relationship between attitudes, subjective norms, and perceived behavioral control towards managers' knowledge-sharing behavior: Empirical study of companies in the Jakarta area]. Ultima Management: Jurnal IImu Manajemen, Vol. 1, 2019, pp. 1-35.

[29] SHAH, H. A - SHERAZ, M. - KHAN, A. U. - KHAN, F. A. - SHAH, L. A. - KHAN, J. - KHAN, A. - KHAN, Z.: Surface and groundwater pollution: the invisible, creeping threat to human health. Civil and Environmental Engineering. Vol.16, Iss.1, 2020, pp. 157-169. 